\title{
Martin Soekefeld, Struggling for Recognition: The Alevi Movement in Germany and in Transnational Space
}

\author{
Berghahn Books, 2008, 304 pages, ISBN-13: 978-1845454784
}

\author{
Joost Jongerden
}

Published online: 16 April 2010

(C) The Author(s) 2010. This article is published with open access at Springerlink.com

\begin{abstract}
Although rendered as natural, identities do not form a natural order. They are defined and delineated by continuous social interventions. Like identities, groups too are socially constructed. Group formation and enrolment are ongoing processes involving ties that are uncertain, fragile, shifting, and controversial. Groups are defined, boundaries marked, patrolled and rendered fixed and durable (Latour 2005). Struggling for Recognition discusses the construction of Alevi identity and group formation among and by Alevis in Germany. The author, Martin Sökefeld, was trained as a social anthropologist at the University of Cologne in Germany, worked as an assistant professor at the Institute of Social and Cultural Anthropology of the University of Hamburg, and is now employed as an assistant professor at the Institute of Social Anthropology of the University of Bern, Switzerland. Struggling for Recognition is not his first publication on Alevis - in fact he elaborates on his earlier work on the construction of Alevi identity and the struggle for definition and recognition of Alevi identity in Germany.

Struggling for Recognition deals with two interlinked concerns. One is the question of how Alevi identity is constructed and maintained. Second, recognizing that if there is something essential to identities it is their innate instability. The author discusses the way in which Alevi identity is being fashioned through acts of commemoration (the 'politics of memory'), taking up a position of opposition to the Turkish state and Sunni-Islam, and identification with modernity and Germany. The second concern is the making of Alevi civil society organizations in Germany. While debating Alevi identity and group formation among and by Alevis residing in Germany. The author also recognizes that identity construction and group formation are enacted in a transnational space among others by discussing how events in Sivas in 1993 and Istanbul in 1995 contributed to the making of Alevi identity and group formation in Germany. Most of the fieldwork for this study has been done in
\end{abstract}

J. Jongerden $(\bowtie)$

Social Science Group, Social Sciences Department, Wageningen University and Research,

Hollandseweg 1, $6706 \mathrm{KN}$ Wageningen, The Netherlands

e-mail: Joost.Jongerden@wur.nl 
Hamburg and Cologne, but the author has also collected data in Istanbul and Hacibektaș (Nevșehir). Both qualitative and quantitative research methods are used, with a strong emphasis on the former. Of the qualitative methods used, participant observation is the most important - the author was employed for a year by the Alevi Cultural Center in Hamburg (Hamburg Alevi Kültür Merkezi).

The main strengths of this book are its constructivist approach and focus on Alevi in Germany (of which a map showing much mentioned places would have been helpful). The body of literature on Alevi identity and group formation in Turkey has been growing over the recent years. Discussion has included the construction of Alevism in opposition to the state, whose policies became based on a Turkish-Sunni Islam synthesis, and also the merging of Alevism with the left. Initially, there was a strong tendency among Alevi to frame Alevism as a social revolutionary current. Principal characters in Alevi culture - such as Ali, Hüseyin, and Pir Sultan Abdalwere presented as leading the fight of the oppressed against dictatorship (White and Jongerden 2003). Alevi symbols melted into socialist ones when militants (on hunger strike) started to use red headbands. Later, however, in the 1980s, leftist parties lost most of their non-Alevi supporters. They transformed into non-religious Alevi organizations, and became actively involved in debates on Alevi identity and Alevism (van Bruinessen 1996). Discussing the phenomena of muhasiplik and a court-like ritual that is part of a Cem ceremony, Sökefeld too gives some striking examples of the way in which Alevi merge Alevism and leftism.

Emphasis in Struggling for Recognition is placed on Alevi identity construction in relation to two relevant others: (Alevi constructions of) Sunni-Turk and German identities. The author observes that Alevis construct their identities by differentiating themselves from Sunni migrants and aligning with the Germans. A key concept in this construction of distinction and alignment is modernity. Alevis position themselves together with the Germans on the side of modernity, with Sunni-Islam contrasted as anti-modern. Interestingly, while Alevism had generally been defined as a culture and expression of universal values, Alevi in Germany started to define themselves in terms of religion, partly due to the German constitution, which allocates particular rights to religious communities.

Although the author mentions differences within and between Alevi organizations (Kemalists, Revolutionaries and Kurdish-Alevi), Sökefeld does not delve into them very deeply. But then, this would have required a different approach-namely a comparison of different Alevi groupings (variously constituted and with, for example, different politics of memory) - rather than an in-depth study of a single grouping. The only part which I did not find very convincing is the author's argument that the Alevis should be considered a diaspora. A transnational perspective on the construction of Alevi identity and group formation is employed throughout the book, and the attempt to squeeze a concept of diaspora into this lacks clarity and is confusing. Moreover, the diaspora argument does not add to the central argument of the book. Instead of analyzing how people have defined and are constructing Alevi identity and Alevism, the diaspora argument focuses on Alevism as defined by the diaspora concept. Notwithstanding this, the book is well written and gives a rich account of Alevi identity construction and group formation in Germany. Struggling for Recognition is an important book and a must read. 
Open Access This article is distributed under the terms of the Creative Commons Attribution Noncommercial License which permits any noncommercial use, distribution, and reproduction in any medium, provided the original author(s) and source are credited.

\section{References}

Latour, B. (2005). Reassembling the social, an introduction to actor-network theory. Oxford: Oxford University Press.

van Bruinessen, M. (1996). Kurds, Turks and the Alevi revival in Turkey. Middle East Report, 26(3), 222225.

White, P., \& Jongerden, J. (2003). Turkey's Alevi enigma, a comprehensive overview. Brill: Leiden \& Boston. 